\title{
Quality Evaluation of Different Forms of Compost and Their Effect in Comparison with Inorganic Fertilizers on Growth and Yield Attributes of Wheat (Triticum aestivum L.)
}

\author{
S. S. Hussain ${ }^{1}$, Tabasum Ara ${ }^{1}$, Firdous Ahmad Raina ${ }^{2}$, G. Gani ${ }^{1}$, Nazir Hussain ${ }^{3}$, Mansoor Hussain ${ }^{3}$ \\ \& S. R. $\operatorname{Dar}^{3}$ \\ ${ }^{1}$ KrishiVigyan Kendra/Extension Training Centre SKUAST-Kashmir, Malangpora (Pulwama) J\&K, India \\ ${ }^{2}$ KrishiVigyan Kendra/Extension Training Centre SKUAST-Kashmir, Kupwara, J\&K, India \\ ${ }^{3}$ KrishiVigyan Kendra/Extension Training Centre SKUAST-Kashmir, Kargil, J\&K, India \\ Correspondence: S. S. Hussain, KrishiVigyan Kendra/Extension Training Centre SKUAST-Kashmir, \\ Malangpora (Pulwama) J\&K, 192122, India. E-mail: darshahnawaz78@rediffmail.com
}

Received: August 19, 2014 Accepted: November 9, 2014 Online Published: December 15, 2014

doi:10.5539/jas.v7n1p154 URL: http://dx.doi.org/10.5539/jas.v7n1p154

\begin{abstract}
The core objective of conducting the current study was to evaluate the chemical compositions of different composts and their effect on wheat yield. Mineral matter content, ash and moisture were higher in all enriched composts and vermicompost in comparison to conventional compost whereas as total organic carbon, water soluble carbon and $\mathrm{C}: \mathrm{N}$ ratio were higher in conventional compost. There was higher variation in the content of nutrients in different composts as that of the conventional one but nitrogen and phosphorus were higher in nitrogen enriched phosphorous-compost and phosphorous enriched vermicompost. Zinc was higher in nitrogen enriched phosphorous-compost, vermicompost and phosphorous enriched vermicompost whereas manganese was higher in vermicompost and phosphorous enriched vermicompost. Biochemical quality stated that conventional compost had lesser amount of total phenol, alkaline and acid phosphatase enzyme activity but higher dehydrogenase activity than those of enriched composts. The more dehydrogenase activity in conventional compost is an indicator of partial decomposition. The time period of decomposition was almost similar (120 \pm 5 days) among the enriched composts, whereas in case of conventional compost, decomposition period was $160 \pm 10$ days.Crop yield was lower in conventional compost but highest yield was obtained by supplying nitrogen enriched phosphorous-compost and phosphorous enriched vermicompost, nitrogen enriched phosphorous-compost provided yield at par to inorganic fertilizer application at $90 \mathrm{~kg} \mathrm{ha}^{-1} \mathrm{~N}, 20 \mathrm{~kg} \mathrm{ha}^{-1} \mathrm{P}$ and 20 $\mathrm{kg} \mathrm{ha}^{-1} \mathrm{~K}$.
\end{abstract}

Keywords: conventional composts, enriched compost, inorganic fertilizer, quality, wheat and yield

\section{Introduction}

Globally, there is enough high quality land to support nearly double the current population. However, Asia already has an acute land shortage because of explosive population growth rate and so is already on the verge of food deficit. Widespread, serious and continuing degradation of India's natural resource base is now reflected in increasing difficulties in achieving growth rates in agriculture. Over 120 million hectares have been declared degraded or problem soils (National Academy of Agricultural Sciences, 2010). But this seems to be a minor problem in the face of the massive and prolonged loss of organic matter and $\mathrm{C}$ in most of the arable lands in India, which have been under the plough for over 2000 years (Royal Commission on Agriculture in India., 1976). Given that for the country in general, crop response or incremental yield per unit of nutrients tends to be lower with increasing fertilizer use per hectare, the evidence for soil organic matter depletion being a prime cause for declining soil health and soil productivity is mounting (Sharda et. al., 2010).

Due to the increasing cost of chemical fertilizers and concern for sustainable soil productivity and ecological stability have been emerged as important issues in Asia, so the search for alternative sources of plant nutrients is imperative (Aulakh et. al., 1997). The diversification of organic sources of plant nutrients as different composts is becoming popular these days and has become an important input in the integrated use of plant nutrient resource sustainability (Rajesh et al., 2003). In agricultural and horticultural fields, the recycling of crop residues 
makes significant contribution in improving the soil properties and crop productivity. Low organic matter is one of the major constraints affecting the productivity of the soils. Organic matter is an important component in improving soil properties and sustaining the productivity of soils in temperate regions where there is a low input of organic matter (Kumar et al., 2013). Composts affect crop growth and yield either directly by supplying nutrients or indirectly by modifying soil properties and stimulating plant growth (Darwish et al., 1995). Increasing the decomposition of organic wastes by enrichment of chemical amendment like rock phosphate, pyrite and urea are some of the modern developments in composting technology. The chemical enrichment accelerates the breakdown of organics into the soluble and mineralized nutrient forms.

Composting has been recognized as a low cost and environmentally sound process for treatment of many organic wastes (Hoitink, 1993). Compost-treated soils had lower $\mathrm{pH}$ and increased levels of organic matter, primary nutrients, and soluble salts (Bevacqua \& Mellano, 1993). In crop studies (Bryan \& Lance., 1991) found that tomatoes grown in compost-amended soils resulted in greater yields. Other benefits from the use of compost include the possible reduction of hazards from nitrate leaching into groundwater compared to those from inorganically fertilized controls (Maynard, 1989). Furthermore, composting and composts have been reported to suppress plant pathogens.

The overall phosphorus and nitrogen use efficiency of applied nitrogen and phosphate inorganic fertilizer is lower than optimal either because of the formation of insoluble P compounds in soil or leaching of highly soluble nitrogen forms (Vance, 2001; Prasad, 2014; Chintala et al., 2013; Chintala et al., 2013). Although composting is an old technique, but improving its nutritional and quality status by blending it with inorganic $\mathrm{N}$ (urea), rock phosphate and biologically active substance is a novel approach. Keeping in view, the situation with reference to organic nutrient sources, low fertility index and low productivity potential, it is directly needed that use of composts enriched with different elements be promoted. Thus, the present study was undertaken to assess the quality of different enriched composts and their impact on crop yield.

\section{Materials and Methods}

Raw materials of paddy straw and fresh cow dung were collected and mixed in the ratio of 1:1 on dry weight basis for making of different types of composts. Conventional compost (CC), phospho compost (PC), nitrogen enriched phosphocompost (NPC), vermicompost (VC) and phospho enriched vermicompost (PVC) were prepared in the pits. For PC, rock phosphate $\left(2.5 \% \mathrm{P}_{2} \mathrm{O}_{5}\right)$ and $\mathrm{AG}$ pyrite $(5 \%)$ were applied, for NPC in addition to enrichment of rock phosphate $\left(2.5 \% \mathrm{P}_{2} \mathrm{O}_{5}\right)$ and pyrite $(5 \%)$ the nitrogen $(0.5 \%)$ was added as urea. For preparation of VC Eiseniafoetida earthworms were introduced to partially decomposed organic matter in the pit after 50 days when the temperature reached 28 to $32^{\circ} \mathrm{C}$.In PVC, rock phosphate $\left(2.5 \% \mathrm{P}_{2} \mathrm{O}_{5}\right)$ was applied at the time of earthworm inoculation. The dimension of the heap was about $0.5 \mathrm{~m}$ high, $1.0 \mathrm{~m}$ wide and $2.0 \mathrm{~m}$ long. In $\mathrm{VC}$ and PVC, one thousand earthworms were inoculated per square meter on the $50^{\text {th }}$ day after the start of the experiment. The decomposition period of PC, NPC, VC and PVC was similar (120 \pm 5 days) while for CC it was (160 \pm 10 days).

Nutrient composition and moisture content in raw materials were analyzed by following the procedures of Association of official agricultural chemists (AOAC, 1970), Table 1. The total organic carbon in the compost was determined by dry combustion at $600{ }^{\circ} \mathrm{C}$ for 8 hours and the percent of carbon was calculated following the equation explained (Waggoner, 1972; Chintala et al., 2013). Water soluble carbohydrates (WSC) were analyzed by using the method of Brink et al. (1960). The nitrogen content in the compost sample was determined by Macro- Kjeldahl method (Jackson, 1973). Phosphorous, potassium and micronutrients were determined by using $1 \mathrm{~g}$ of dry compost sample and digested with tri-acid mixture $\left(\mathrm{HNO}_{3}: \mathrm{HClO}_{4}: \mathrm{H}_{2} \mathrm{SO}_{4}\right.$ in 9:3:1 ratio) on a hot plat at $180-200{ }^{\circ} \mathrm{C}$. Phosphorous extracted solution was estimated by spectrophotometer method (Jackson, 1973), potassium was determined by flame photometer method given by Toth et al. (1948), and the micro-nutrients (Zn, $\mathrm{Mn}, \mathrm{Cu}$ and $\mathrm{Fe}$ ) were estimated by using atomic absorption spectrophotometer method (Lindsay \& Norvell, 1978). Lignin and cellulose content was fractioned by following the procedure given by Rowland and Roberts (1974). The total phenol content, dehydrogenase enzyme activity and acid-alkaline phosphate activities in compost samples were estimated by using recommended methods (Bray \& Thrope, 1954; Casida et al., 1964; Tabatabai \& Bremner, 1969). 
Table 1. Initial chemical composition of paddy straw and Cow dung used for composting

\begin{tabular}{ccccccccc}
\hline Raw Materials & $\begin{array}{c}\text { Ash } \\
(\%)\end{array}$ & $\begin{array}{c}\text { Total C } \\
(\%)\end{array}$ & $\begin{array}{c}\text { Total N } \\
(\%)\end{array}$ & $\begin{array}{c}\mathrm{C} / \mathrm{N} \\
\text { Ratio }\end{array}$ & $\begin{array}{c}\text { Phenol } \\
\left(\mu \mathrm{g}^{-1}\right)\end{array}$ & $\begin{array}{c}\text { Lignin } \\
(\%)\end{array}$ & $\begin{array}{c}\text { Cellulose } \\
(\%)\end{array}$ & $\begin{array}{c}\text { L/C } \\
\text { Ratio }\end{array}$ \\
\hline Paddy Straw & 6.05 & 43.2 & 0.75 & 57.6 & 46.5 & 10.5 & 36.3 & 3.45 \\
Cow dung & 28.0 & 34.5 & 0.59 & 58.5 & 15.5 & 8.03 & 13.4 & 0.60 \\
\hline
\end{tabular}

The field experiment in 2012 was conducted on sandy loam (TypicUstochrept) at Malangpora (Pulwama-KVK Research and Extension Centre), India in to assess the effect of compost and inorganic fertilizer application on the growth and yield of wheat. Soil samples $(0-15 \mathrm{~cm}$ surface soil layer) were collected randomly from various places of the experimental fields and mixed to make the composite samples. The composite soil sample of experimental field was analyzed for various physical and chemical characteristics. The soil had the following characteristics: organic carbon $3.90 \mathrm{~g} \mathrm{~kg}^{-1}$, base saturation percentage $22.13 \%$, ECe $1.14 \mathrm{dSm}^{-1}, \mathrm{pH} 7.2$, total nitrogen $0.57 \mathrm{~g} \mathrm{~kg}^{-1}$, total phosphorus $0.50 \mathrm{~g} \mathrm{~kg}^{-1}$, total potash $3.4 \mathrm{~g} \mathrm{~kg}^{-1}, \mathrm{C}: \mathrm{N}$ ratio 6.90 and bulk density 1.58 $\mathrm{Mg} \mathrm{m}^{-3}$. Wheat (Tritium aestivum $\mathrm{L}$.) variety "SW-1" seed was sown at $100 \mathrm{~kg} \mathrm{ha}^{-1}$ in $10 \mathrm{~m}^{2}$ plots on $15^{\text {th }}$ November, 2012. Depending on treatment, compost was incorporated thoroughly into the soil plough layer 15 days before sowing of wheat and inorganic NPK in two comparison treatments were applied at sowing time using urea, diammonium phosphate (DAP) and muriate of potash (MOP). For calculating grain number per ear head, 20 ear heads in each treatment were collected and grain count of these were scaled as $<31,31$ to 40,41 to 50,51 to 60 and $>60$ grains per ear head. The total count was converted to percent. The grain and straw yield were recorded at crop harvest. Grain and shoot samples of plants were analyzed for NPK contents (Ryan et al., 2001) and their total uptake were calculated. The data was analyzed statistically according to method of Steel et al. (1997). Means were compared by Duncan's multiple range test (DMRT) at 5 percent probability (Duncan, 1955).

\section{Result and Discussion}

\subsection{Quality Evaluation of Different Composts}

Chemical compositions of diverse composts at the completion of decomposition processes were assessed and results were shown in Table 2. There was no significant variation in moisture percent of different types of composts. Data showed that water soluble carbon (WSC) value was almost double in conventional compost (CC) than those of chemically enriched composts and vemicompost. The least WSC of 0.84 was found in phosphorus enriched vermicompost (PVC) followed by value of 0.92 in vemicompost (VC) and maximum WSC of 1.09 in case of phosphorus compost (PC), the results agree with the earlier findings reported by Singh and Gangualy (2005) who revealed that well enriched composts have lesser amount of WSC than those of conventional composts.

Table 2. Chemical compositions of different composts at the end of decomposition

\begin{tabular}{cccccccccccc}
\hline Composts $^{*}$ & $\begin{array}{c}\text { Moisture } \\
(\%)\end{array}$ & $\begin{array}{c}\text { WSC } \\
\left(\mathrm{g} \mathrm{kg}^{-1}\right)\end{array}$ & $\begin{array}{c}\text { Ash } \\
(\%)\end{array}$ & $\begin{array}{c}\mathrm{TC} \\
\left(\mathrm{g} \mathrm{kg}^{-1}\right)\end{array}$ & $\begin{array}{c}\mathrm{C} / \mathrm{N} \\
\text { Ratio }\end{array}$ & $\begin{array}{c}\mathrm{N} \\
\left(\mathrm{g} \mathrm{kg}^{-1}\right)\end{array}$ & $\begin{array}{c}\mathrm{P}_{2} \mathrm{O}_{5} \\
\left(\mathrm{~g} \mathrm{~kg}^{-1}\right)\end{array}$ & $\begin{array}{c}\mathrm{K} \\
\left(\mathrm{g} \mathrm{kg}^{-1}\right)\end{array}$ & $\begin{array}{c}\mathrm{Mn} \\
\left(\mathrm{mg} \mathrm{kg}^{-1}\right)\end{array}$ & $\begin{array}{c}\mathrm{Zn} \\
\left(\mathrm{mg} \mathrm{kg}^{-1}\right)\end{array}$ & $\begin{array}{c}\mathrm{Cu} \\
\left(\mathrm{mg} \mathrm{kg}^{-1}\right)\end{array}$ \\
\hline $\mathrm{CC}$ & $42.0 \mathrm{a}$ & $2.05 \mathrm{a}$ & $47.6 \mathrm{~b}$ & $23.8 \mathrm{a}$ & $20.5 \mathrm{a}$ & $1.16 \mathrm{e}$ & $1.84 \mathrm{e}$ & $0.69 \mathrm{~b}$ & $287 \mathrm{c}$ & $81 \mathrm{~b}$ & $41 \mathrm{~b}$ \\
$\mathrm{VC}$ & $46.5 \mathrm{a}$ & $0.92 \mathrm{~b}$ & $52.0 \mathrm{a}$ & $21.6 \mathrm{~b}$ & $12.8 \mathrm{~b}$ & $1.69 \mathrm{~cd}$ & $2.00 \mathrm{~d}$ & $0.82 \mathrm{a}$ & $325 \mathrm{~b}$ & $100 \mathrm{a}$ & $49 \mathrm{a}$ \\
$\mathrm{PVC}$ & $48.2 \mathrm{a}$ & $0.84 \mathrm{~b}$ & $54.5 \mathrm{a}$ & $20.9 \mathrm{~b}$ & $11.7 \mathrm{~d}$ & $1.79 \mathrm{~b}$ & $3.83 \mathrm{a}$ & $0.85 \mathrm{a}$ & $370 \mathrm{a}$ & $104 \mathrm{a}$ & $52 \mathrm{a}$ \\
$\mathrm{PC}$ & $43.8 \mathrm{a}$ & $1.09 \mathrm{~b}$ & $53.1 \mathrm{a}$ & $21.0 \mathrm{~b}$ & $12.2 \mathrm{c}$ & $1.72 \mathrm{c}$ & $3.63 \mathrm{bc}$ & $0.80 \mathrm{a}$ & $320 \mathrm{~b}$ & $81 \mathrm{~b}$ & $48 \mathrm{a}$ \\
$\mathrm{NPC}$ & $44.4 \mathrm{a}$ & $0.95 \mathrm{~b}$ & $54.3 \mathrm{a}$ & $20.6 \mathrm{~b}$ & $11.3 \mathrm{e}$ & $1.83 \mathrm{a}$ & $3.75 \mathrm{ab}$ & $0.84 \mathrm{a}$ & $325 \mathrm{~b}$ & $104 \mathrm{a}$ & $54 \mathrm{a}$ \\
\hline
\end{tabular}

Values sharing similar letter (s) in a column are non-significant at $\mathrm{P}<0.05$, according to Duncan's multiple range test.

*CC is conventional compost, $\mathrm{VC}$ is vermicompost, PVC is phosphorus enriched vemricompost, $\mathrm{PC}$ is phosphorus compost and NPC is nitrogen enriched phosphorus compost.

The ash content was higher in different enriched composts and vermicomposts as compared to the conventional compost. However total organic carbon values and C:N ratio were lower in the different enriched composts and 
vermicomposts than that of $\mathrm{CC}$. The difference in $\mathrm{C}: \mathrm{N}$ ratio was because of higher nitrogen content of diverse chemically enriched and vermicomposts. NPK content in CC was less than those of enriched compost. The phosphorous content of the enriched composts ranged from 2 to $3 \%$ and were higher than in $\mathrm{CC}$ due to addition of rock phosphate in all three composts. However PVC showed slightly higher P value, similar to earlier work by Sharma et al. (2004). Micronutrient content (Mn, $\mathrm{Zn}, \mathrm{Fe}$, and $\mathrm{Cu}$ ) was higher in enriched compost as compared to CC which was also observed in previous studies (Rajesh et al., 2003).

The data in Table 3 revealed that the increase in phenol content in different enriched composts is one of the indicators of completion of humification and the composts had reached to the maturity level, while higher dehydrogenase activity in $\mathrm{CC}$ indicates that the compost is still being decomposed and hence it exhibited higher microbial activity.In fully matured compost decomposition is slowed down and hence dehydrogenase activity is lower. Alkaline phosphatase indicates of phosphorus mineralization power by the microorganisms involved in P-cycling. The PC, NPC, VC, and PVC had higher values of alkaline phosphatase than that of CC. The higher values of alkaline and acid phosphatase enzyme activity in the PC, NPC, and PVC may be due to the use of rock phosphate amendment in the composting process which may accelerate the growth of microorganisms related to phosphorous mineralization.

Table 3. Biochemical components of various types of compost

\begin{tabular}{lllll}
\hline Composts & $\begin{array}{l}\text { Total phenol }(\mathrm{mg} \\
\left.\mathrm{kg}^{-1} \text { compost }\right)\end{array}$ & $\begin{array}{l}\text { Dehydrogenase }(\mathrm{mg} \text { TPF } \\
\left.\mathrm{kg}^{-1} \text { compost } \mathrm{hr}^{-1}\right)\end{array}$ & $\begin{array}{l}\text { Alkaline phosphatase }(\mathrm{mg} \text { p-nitro } \\
\left.\text { phenol } \mathrm{kg}^{-1} \text { compost } \mathrm{hr}^{-1}\right)\end{array}$ & $\begin{array}{l}\text { Acid phosphatase (mg p-nitro } \\
\left.\mathrm{phenol} \mathrm{kg}^{-1} \mathrm{compost} \mathrm{hr}^{-1}\right)\end{array}$ \\
\hline $\mathrm{CC}$ & $86.0 \pm 1.14$ & $51.0 \pm 0.85$ & $445.2 \pm 4.68$ & $384.0 \pm 7.63$ \\
$\mathrm{VC}$ & $94.0 \pm 1.80$ & $46.0 \pm 0.50$ & $503.1 \pm 5.82$ & $406.0 \pm 5.42$ \\
$\mathrm{PVC}$ & $102.5 \pm 0.65$ & $43.6 \pm 0.29$ & $576.0 \pm 4.90$ & $436.2 \pm 4.86$ \\
$\mathrm{PC}$ & $104.1 \pm 1.14$ & $47.2 \pm 0.47$ & $541.1 \pm 5.60$ & $461.0 \pm 5.73$ \\
$\mathrm{NPC}$ & $109.5 \pm 2.63$ & $44.7 \pm 1.09$ & $566.2 \pm 11.09$ & $439.0 \pm 5.93$ \\
\hline
\end{tabular}

*CC is conventional compost, $\mathrm{VC}$ is vermicompost, $\mathrm{PVC}$ is phosphorus enriched vemricompost, $\mathrm{PC}$ is phosphorus compost and NPC is nitrogen enriched phosphorus compost.

\subsection{Comparative Effect of Inorganic Fertilizers and Chemically Enriched Composts on Growth and Yield Attributes of Wheat}

Adding inorganic fertilizers and enriched composts significantly increased grain, straw yield, harvest index and nutrient uptake as compared to $\mathrm{CC}$ which directly showed its effect on grain number per ear head (Tables 4 and 5). On the average more than 45 grains per ear head were found when inorganic fertilizers or well enriched composts were used, but in case of CC the grains per ear head were very low which directly lead to yield reduction. Sole application of mineral fertilizer nitrogen at higher rates or enriched composts increased total nutrients by grain and straw not only by promoting dry matter production but also by increasing the nutrient concentrations of grain and straw. Grain, straw yield, and total nutrient uptake were significantly higher in plots treated with $120 \mathrm{~kg} \mathrm{ha}^{-1} \mathrm{~N}, 40 \mathrm{~kg} \mathrm{ha}^{-1} \mathrm{P}$, and $40 \mathrm{~kg} \mathrm{ha}^{-1}$ (Tables 4 and 5).The beneficial effects of NPK in increasing grain, straw yield, grains per ear head and nutrient uptake can be explained on the basis that NPK improved the growth of the plant and enhanced the uptake of other nutrients which might have increased the photosynthesis and photosynthates translocated to different parts for promoting meristematic development and consequently increased the yield of crop, similar findings were earlier reported by Deshmukh and Tiwari (1996). Comparing the effects of composts, the treatment involving well enriched composts like NPC and PVC provided yield equivalent to $\mathrm{N}_{90} \mathrm{P}_{20} \mathrm{~K}_{20}$ because of their narrow C:N ratio which might release nutrients in synchrony with plant growth demand and give higher yields, in agreement with Maynard (1989). On the contrary, treatment with $\mathrm{CC}$ gave lowest grain, straw yield, grains per ear head and nutrient possibly due to immobilization of soil $\mathrm{N}$ in this treatment because of its greater $\mathrm{C}: \mathrm{N}$ ratio and their antagonistic effect on other nutrients. The grain, straw yield, and total nutrient uptake were dependent mainly on mineral nutrient status throughout the growth stages which was observed to be better in NPC and PVC incorporated treatments. 
Table 4. Effect of conventional compost, different enriched composts and vermicompost in comparison to inorganic NPK fertilizers on the yield and yield attributing factors of wheat

\begin{tabular}{|c|c|c|c|c|c|c|c|c|c|}
\hline \multirow{2}{*}{ Treatments** } & \multirow{2}{*}{$\begin{array}{l}\text { Grain Yield } \\
\left(\mathrm{t} \mathrm{ha}^{-1}\right)\end{array}$} & \multirow{2}{*}{$\begin{array}{l}\text { Straw Yield } \\
\left(\mathrm{t} \mathrm{ha}^{-1}\right)\end{array}$} & \multirow{2}{*}{ Harvest Index } & \multirow{2}{*}{$\begin{array}{l}\text { Grains } \\
\text { Earhead }^{-1}\end{array}$} & \multicolumn{5}{|c|}{ Grain Count Scale (\%) } \\
\hline & & & & & $<31$ & $31-40$ & $41-50$ & $51-60$ & $>60$ \\
\hline $\mathrm{N}_{90} \mathrm{P}_{20} \mathrm{~K}_{20}$ & $3.10 \mathrm{c}$ & $3.75 \mathrm{bc}$ & $0.453 \mathrm{bc}$ & $47.5 \mathrm{bc}$ & 5 & 35 & 25 & 30 & 5 \\
\hline $\mathrm{N}_{120} \mathrm{P}_{40} \mathrm{~K}_{40}$ & $3.60 \mathrm{a}$ & $4.10 \mathrm{a}$ & $0.468 \mathrm{a}$ & $52.5 \mathrm{a}$ & 0 & 15 & 35 & 40 & 10 \\
\hline $\mathrm{CC}_{12}$ & $2.35 \mathrm{e}$ & $3.25 \mathrm{e}$ & $0.420 \mathrm{e}$ & $30.0 \mathrm{f}$ & 30 & 45 & 20 & 5 & 0 \\
\hline $\mathrm{VC}_{12}$ & $2.85 \mathrm{~d}$ & $3.60 \mathrm{~d}$ & $0.442 \mathrm{~d}$ & $37.5 \mathrm{e}$ & 20 & 35 & 30 & 15 & 0 \\
\hline $\mathrm{PVC}_{12}$ & $3.07 \mathrm{c}$ & $3.70 \mathrm{~cd}$ & $0.453 b c$ & $44.0 \mathrm{~cd}$ & 10 & 40 & 25 & 25 & 0 \\
\hline $\mathrm{PC}_{12}$ & $2.95 \mathrm{~d}$ & $3.65 \mathrm{~d}$ & $0.447 \mathrm{~cd}$ & $41.5 \mathrm{~d}$ & 15 & 40 & 25 & 20 & 0 \\
\hline $\mathrm{NPC}_{12}$ & $3.18 \mathrm{~b}$ & $3.80 \mathrm{~b}$ & $0.456 \mathrm{~b}$ & $50.5 \mathrm{ab}$ & 5 & 30 & 25 & 35 & 5 \\
\hline
\end{tabular}

Values sharing similar letter (s) in a column are non-significant at $\mathrm{P}<0.05$, according to Duncan's multiple range test.

** In case of inorganic fertilizers (NPK) subscript represents application $\mathrm{kg} \mathrm{ha}^{-1}$, whereas in case of composts subscript represents application $\mathrm{t} \mathrm{ha}^{-1}$.

Table 5. Effect of conventional compost, different enriched composts and vermicompost in comparison to inorganic NPK fertilizers on nutrient uptake and soil properties

\begin{tabular}{llllll}
\hline Treatments** & $\begin{array}{l}\text { Nitrogen Uptake } \\
\left(\mathrm{kg} \mathrm{ha}^{-1}\right)\end{array}$ & $\begin{array}{l}\text { Phosphorus Uptake } \\
\left(\mathrm{kg} \mathrm{ha}^{-1}\right)\end{array}$ & $\begin{array}{l}\text { Potassium Uptake } \\
\left(\mathrm{kg} \mathrm{ha}^{-1}\right)\end{array}$ & $\begin{array}{l}\text { Organic Carbon } \\
\left(\mathrm{g} \mathrm{kg}^{-1}\right)\end{array}$ & $\mathrm{pH}$ \\
\hline $\mathrm{N}_{90} \mathrm{P}_{20} \mathrm{~K}_{20}$ & $72.3 \mathrm{bc}$ & $21.4 \mathrm{bc}$ & $91.9 \mathrm{c}$ & $0.395 \mathrm{e}$ & $7.2 \mathrm{a}$ \\
$\mathrm{N}_{120} \mathrm{P}_{40} \mathrm{~K}_{40}$ & $94.5 \mathrm{a}$ & $28.6 \mathrm{a}$ & $128.6 \mathrm{a}$ & $0.405 \mathrm{~d}$ & $7.2 \mathrm{a}$ \\
$\mathrm{CC}_{12}$ & $46.6 \mathrm{f}$ & $14.2 \mathrm{f}$ & $53.5 \mathrm{f}$ & $0.455 \mathrm{a}$ & $7.1 \mathrm{ab}$ \\
$\mathrm{VC}_{12}$ & $52.6 \mathrm{e}$ & $16.8 \mathrm{de}$ & $68.3 \mathrm{e}$ & $0.439 \mathrm{~b}$ & $7.0 \mathrm{bc}$ \\
$\mathrm{PVC}_{12}$ & $64.6 \mathrm{~d}$ & $19.5 \mathrm{~cd}$ & $81.8 \mathrm{~cd}$ & $0.428 \mathrm{bc}$ & $6.9 \mathrm{~cd}$ \\
$\mathrm{PC}_{12}$ & $58.3 \mathrm{e}$ & $18.2 \mathrm{~cd}$ & $74.4 \mathrm{de}$ & $0.435 \mathrm{~b}$ & $6.9 \mathrm{~cd}$ \\
$\mathrm{NPC}_{12}$ & $77.1 \mathrm{~b}$ & $23.5 \mathrm{~b}$ & $107.5 \mathrm{~b}$ & $0.422 \mathrm{c}$ & $6.8 \mathrm{~d}$
\end{tabular}

Values sharing similar letter (s) in a column are non-significant at $\mathrm{P}<0.05$, according to Duncan's multiple range test.

** In case of inorganic fertilizers (NPK) subscript represents application $\mathrm{kg} \mathrm{ha}^{-1}$, whereas in case of composts subscript represents application $\mathrm{t} \mathrm{ha}^{-1}$.

\section{Conclusion}

The decomposition period was reduced to $70 \pm 5$ days in chemically-enriched compost and vermincompost as compared to conventional compost. Phospho-compost (PC), nitrogen-enriched phospho-compost (NPC), Vermicompost and Phospho-enriched vermicompost (PVC) were observed to be higher in nutrients status and enhanced the soil biological quality compared to conventionally produced compost. NPC and PVC are more promising composts and enhanced the growth and yield parameters of wheat equivalent to inorganic fertliser treatment.

\section{Acknowledgements}

Authors thank the Programme Co-Coordinator KVK/ETC Pulwama J\&K and Co-principal investigator NICRA project; Prof. Dr. Tabasum Ara, for providing necessary facilities for this study.

\section{References}

AOAC. (1970). Official Methods of Analysis. Association of Official Agricultural Chemists, Washington, D.C.

Aulakh, M. S., \& Singh, B. (1997). Nitrogen losses and fertilizer nitrogen use efficiency in irrigated porous soils. Nutrient Cycling in Agroecosystem, 7, 1-16. 
Bevacqua, R. F., Bray, H. G., \& Thrope, W. V. (1954). Analysis of phenolic compounds of interest in metabolism. Methods of Biochemistry Analysis, 1, 27-52.

Bryan, H. H., \& Lance, C. J. (1991). Compost trials on vegetables and tropical crops. Biocycle, 32, 36-37.

Casida, L. E., Klein, D. A., \& Santoro, T. (1964). Soil dehydrogenase activity. Soil Science, 98, 371-376. http://dx.doi.org/10.1097/00010694-196412000-00004

Chintala, R., Mollinedo, J., Schumacher, T. E., Malo, D. D., Papiernik, S., Clay, D. E., ... Gulbrandson, D. W. (2013). Nitrate sorption and desorption by biochars produced from microwave pyrolysis. Microporous and Mesoporous Materials, 179, 250-257. http://dx.doi.org/10.1016/j.micromeso.2013.05.023

Chintala, R., Schumacher, T. E., McDonald, L. M., Clay, D. E., Malo, D. D., Clay, S. A., ... Julson, J. L. (2013). Phosphorus sorption and availability in biochars and soil biochar mixtures. CLEAN-Soil Air Water, 41(9999), 1-9.

Deshmukh, S. C., \& Tiwari, S. C. (1996). Efficiency of slow releasing nitrogen fertilizer in rice on partially reclaimed vertisols. Ind. J. Agron, 41, 586-590.

Duncan, D. B. (1955). Multiple range and multiple F-test. Biometrics, 11, 1-42. http://dx.doi.org/10.2307/3001478

Darwish, O. H., Persaud, N., \& Martens, D. C. (1995). Effect of long-term application of animal manure on physical properties of three soils. Plant and Soil, 176, 289-295. http://dx.doi.org/10.1007/BF00011793

Hoitink, H. A. J. (1993). Proceedings Review: International Symposium on composting research. Compost Science and Utilization, Spring 1993, 37.

Maynard, A. (1989). Agricultural composts as amendments reduce nitrate leaching. Frontiers of Plant Science, $24,2-4$.

Jackson, M. L. (1973). Soil Chemical Analysis. New Delhi: Prentice Hall of India Pvt. Ltd. http://dx.doi.org/10.1021/ac60324a033

Kumar, S., Nakajima, T., Mbonimpa, E. G., Gautam, S., Somireddy, U. R., Kadono, A., ... Fausey, N. (2014). Long-term tillage and drainage influences on soil organic carbon dynamics, aggregate stability, and carbon yield. Soil Science \& Plant Nutrition, 60(1), 108-118. http://dx.doi.org/10.1080/00380768.2013.878643

Lindsay, W. L., \& Norvell, W. A. (1978). Development of DTPA soil test for zinc, iron, manganese and copper. Soil Science Society of America Journal, 52, http://dx.doi.org/10.2136/sssaj1978.03615995004200030009x

Mellano, V. (1993). Sewage sludge compost's cumulative effects on crop growth and soil properties. Compost Science and Utilization, Spring 1993, 34-37.

NAAS. (2010). Degraded and Wastelands of India; Status and Spatial Distribution. Directorate of Information and Publications of Agriculture, ICAR, Pusa, New Delhi.

Prasad, R. (2014). Using nitrogen and phosphorus budgets as effective tools for assessing nitrogen and phosphorus losses from agricultural systems (Ph.D. diss., Univ. of Florida, Gainesville).

Rajesh, C., Reddy, K. S., Naidu, M. V. S., \& Ramavataram, N. (2003). Production and evaluation of compost and vermicompost from solid organic wastes. Asian Journal of Microbiology, Biotechnology, and Environmental Science, 5, 307-311.

Rowland, A. P., \& Roberts, J. D. (1994). Lignin and cellulose fraction in decomposition studies using acid detergent fibre methods. Communications in Soil Science and Plant Analysis, 25, 269-277. http://dx.doi.org/10.1080/00103629409369035

Royal Commission on Agriculture in India. (1976). Agricole Publishing Academy, New Delhi, India.

Ryan, J., Estefan, G., \& Rashid, A. (2001). Soil and Plant Analysis: Laboratory Mannual (p. 172). Int. Centre Agri. Res. in Dry Areas (ICARDA) Aleppo.

Sharda, V. N., Dogra, P., \& Prakash, C. (2010). Assessment of Production Losses Due to Water Erosion in Rainfed Areas of India. Journal of Soils and Water Conservation, 65(2), 79-91. http://dx.doi.org/10.2489/jswc.65.2.79 
Sharma, V., Kanwar, K., \& Dev, S. P. (2004). Efficient recycling of obnoxious weed plants (Lantana camara L.) and Congress grass (Parthenium hysterophorus L.) as organic manure through vermicomposting. Journal of the Indian Societyof Soil Science, 52, 112-114.

Steel, R. G. D., Torrie, J. H., \& Dicky, D. A. (1997). Principles and Procedures of Statistics - A Biometrical Approach (3rd ed., pp. 204-227). McGraw-Hill Book International Co., Singapore.

Tabatabai, M. A., \& Bremner, J. M. (1969). Use of nitrophenyl for assay of soil phosphatase activity. Soil Biology and Biochemistry, 1, 301-307. http://dx.doi.org/10.1016/0038-0717(69)90012-1

Toth, S. S., Prince, A. I., Wallace, A., \& Mikkelsen, D. S. (1948). Rapid quantitative determination of eight mineral elements in plant tissue by a systematic produce involving use of a flame photometer. Soil Science, 66, 459-466. http://dx.doi.org/10.1097/00010694-194812000-00006

Vance, C. P. (2001). Symbiotic nitrogen fixation and phosphorus acquisition: plant nutrition in a world of declining renewable resources. Plant Physiology, 127, 390-397. http://dx.doi.org/10.1104/pp.010331

Waggoner, P. E. (1972). Bull Connecticut. Agricultural Experimental Station 754.

Singh, A. B., \& Ganguly, T. K. (2005). Quality Comparison of Conventional Compost, Vermicompost and Chemically-enriched Compost. Journal of the Indian Society of Soil Science, 53(3), 352-255.

\section{Copyrights}

Copyright for this article is retained by the author(s), with first publication rights granted to the journal.

This is an open-access article distributed under the terms and conditions of the Creative Commons Attribution license (http://creativecommons.org/licenses/by/3.0/). 